\title{
Partition of Copper between Dissolved and Particulate Phases Using Aluminum Oxide as an Aquatic Model Phase: Effects of pH, Solids and Organic Matter
}

\author{
Marco T. Grassi ${ }^{a^{*}}$, Bo Shi ${ }^{b}$ and Herbert E. Allen ${ }^{c}$ \\ a Departamento de Química, Universidade Federal do Paraná, C.P. 19081, 81531-990 Curitiba - PR, Brazil \\ ${ }^{\mathrm{b}}$ Kimberly-Clark Corporation, Environmental Technology Division, Neenah, WI 54956, U.S.A. \\ ${ }^{\mathrm{c}}$ Department of Civil and Environmental Engineering, University of Delaware, Newark, DE 19716, U.S.A.
}

\begin{abstract}
A adsorção de cobre sobre óxido de alumínio modificado, em meio aquoso, foi avaliada neste trabalho. A modificação do $\mathrm{Al}_{2} \mathrm{O}_{3}$ foi realizada através da adsorção de ácido húmico comercial à sua superfície. A adsorção do cobre foi governada por fatores tais como $\mathrm{pH}$, teores de matéria orgânica (particulada e dissolvida) e concentração do material sólido. A adsorção do metal aumentou com o aumento do $\mathrm{pH}$ e igualmente com o aumento nos teores de matéria orgânica na fase particulada. $\mathrm{O}$ coeficiente de partição $\left(\mathrm{K}_{\mathrm{d}}\right)$ do cobre diminuiu com o aumento na concentração do material sólido. Os valores de $\mathrm{K}_{\mathrm{d}}$ foram sempre mais elevados na região de $\mathrm{pH}$ neutro e decresceram tanto para regiões mais baixas quanto mais elevadas de $\mathrm{pH}$. Também foi observado um decréscimo na adsorção do cobre quando a concentração de matéria orgânica dissolvida foi aumentada.
\end{abstract}

The sorption of copper ions from aqueous solutions onto modified aluminum oxide was investigated as a function of $\mathrm{pH}$, solids concentration and both particulate and dissolved organic matter. The aluminum oxide studied was modified by adsorption of humic acid. The $\mathrm{pH}$ value, organic matter content, and solids concentration dominated copper adsorption onto modified aluminum oxide. The adsorption of copper increased with increasing $\mathrm{pH}$. An increase in particulate organic carbon resulted in an enhanced copper uptake. The partition coefficient $\left(\mathrm{K}_{\mathrm{d}}\right)$ of copper decreased as the solids concentration increased. Copper partitioning was maximal in the neutral $\mathrm{pH}$ range and decreased at either low or high $\mathrm{pH}$ values. There was also a decrease in copper adsorption with increasing dissolved organic matter concentration.

Keywords: copper, aluminum oxide, partitioning, natural waters, humic acids

\section{Introduction}

The partition of metals between the dissolved and particulate phases is a subject of major interest due to its influence concerning the fate and effects of metals in the aquatic environment. In addition to the free metal ions and dissolved complexes, metals in natural waters are also associated with suspended particulate matter (SPM). SPM relates to aggregated materials including biotic and abiotic components ${ }^{1}$. In most systems, SPM represents some combinations of inorganic material such as clays, hydrous metal oxides, and organic matter, both detrital and living. Because of adsorption and scavenging nature, SPM is often the major transport vector for metals ${ }^{2}$. Stiff ${ }^{3}$ and Windom et al. ${ }^{4}$ reported that up to $70 \%$ of total copper present in natural water was bound in the particulate phase.

\footnotetext{
*e-mail: mtgrassi@quimica.ufpr.br
}

Processes controlling the partitioning between the solid and aqueous phase have been reviewed by $\mathrm{McBride}^{5}$ and Evans ${ }^{6}$. Of the three principal mechanisms - precipitation, ion exchange, and adsorption - the most important in the present situation is adsorption.

There is a large body of literature reporting metal adsorption and desorption using soils ${ }^{7-9}$, metal oxides ${ }^{2,10,11}$, natural suspended solids ${ }^{12-14}$, and other solids ${ }^{15-17}$. In general, none of the solid particles utilized could fully represent those existing in a real water column.

Natural suspended particulate matter has not been commonly studied due to difficulties in concentrating solids from surface water ${ }^{18}$. Mostly, the suspended solids concentration in surface water is around 5 to $20 \mathrm{mg} \mathrm{L}^{-1}$. Because of that a fairly large sample volume of water needs to be processed to obtain enough suspended solids to perform adsorption or desorption experiments. Methods for SPM concentration from natural waters include settling, 
centrifugation, flocculation, membrane filtration, reverse osmosis, and hollow fiber ultrafiltration ${ }^{19}$. All of these suffer from many shortcomings in handling colloidal materials. Coagulation of small particles is also a problem due to the fact that there might be a significant change in the original characteristics of the particles. Horowitz et al. ${ }^{20}$ reported several continuous flow-through devices to process whole-water samples on-line. The systems retain solids while discharging a clarified effluent. The major advantage is the fast processing of a large amount of water and also negligible amount of metals and organic matter are carried over, so the concentrated suspension can be used for subsequent experiments.

It is generally accepted that most particles in organicrich aquatic systems are coated with a thin film of organic matter, in particular humic substances ${ }^{21,22}$. The role of natural organic matter (NOM) in governing metal fate in water environment is evident. The NOM contains both hydrophilic and hydrophobic sites ${ }^{23}$. Preferably, the hydrophilic substructures of humic substances are attached to particle surfaces. The partitioning of metal is then strongly affected by particulate organic matter ${ }^{24,25}$. Natural suspended solids usually have a particulate organic coating, which are typically about 2 to $3 \%$ of the total solids load ${ }^{26}$. These coatings provide to the surface important characteristics in the exchange of trace metals between solution and solid phases. The high adsorption dependency on $\mathrm{pH}$ results from the surface chemistry of organic materials. Similarly to soil particles, suspended solids in the natural water also have $\mathrm{pH}$-dependent surface characteristics, which will affect its reaction with protons and with certain functional groups of humic substances 6,27 .

The ionization of an amphoteric metal oxide can be represented by two protolysis reactions ${ }^{28,29}$ :

$\equiv \mathrm{S}-\mathrm{OH}_{2}^{+} \Leftrightarrow \equiv \mathrm{S}-\mathrm{OH}+\mathrm{H}^{+}$

and

$\equiv \mathrm{S}-\mathrm{OH} \Leftrightarrow \equiv \mathrm{S}-\mathrm{O}^{-}+\mathrm{H}^{+}$

The corresponding stability constants are

$\mathrm{K}_{\text {cond.,al }}=\frac{[\equiv \mathrm{S}-\mathrm{OH}]\left\{\mathrm{H}^{+}\right\}}{\left[\equiv \mathrm{S}-\mathrm{OH}_{2}^{+}\right]}$

and

$\mathrm{K}_{\text {cond...a2 }}=\frac{\left[\equiv \mathrm{S}-\mathrm{O}^{-}\right]\left\{\mathrm{H}^{+}\right\}}{[\equiv \mathrm{S}-\mathrm{OH}]}$

where brackets, [ ], indicate concentration in $\mathrm{mol} \mathrm{L}^{-1}$ and the braces, \{\} , indicate the activity of the enclosed chemical species. The corresponding intrinsic constants are products of conditional stability constants and an electrostatic factor, $\exp \left(\frac{\mathrm{e} \psi_{\mathrm{o}}}{\mathrm{kT}}\right)$, where e is the electron charge, $\Psi_{\mathrm{o}}$ is the surface potential, $\mathrm{k}$ is the Boltzman constant, and $\mathrm{T}$ is the absolute temperature ${ }^{30}$. The fraction of positive, neutral and negative surface groups can be predicted for any given $\mathrm{pH}$ value using similar calculations as for a diprotic acid. At $\mathrm{pH}$ lower than $\mathrm{pH}_{\mathrm{ZPC}}$ (zero point of charge), $\equiv \mathrm{S}_{-} \mathrm{O}^{-}$is the main species and the surface is negatively charged. A comprehensive adsorption model must account for the increase binding at increasing $\mathrm{pH}^{31}$. In the natural water $\mathrm{pH}$ range, $\equiv \mathrm{S}-\mathrm{OH}$ is predominant and it can be used to represent particle species. Copper adsorption on such particles can be expressed as follows ${ }^{22}$ :

$\equiv \mathrm{S}-\mathrm{OH}+\mathrm{Cu}^{2+} \Leftrightarrow \quad \equiv \mathrm{S}-\mathrm{OCu}^{+}+\mathrm{H}^{+}$

Proton release associated with adsorption of a copper ion is potentially a constraint on the type of surface species postulated ${ }^{33}$. Fu et al. ${ }^{17}$ demonstrated that the binding of cadmium ions and protons on oxic sediments was indistinguishable from their binding to humic materials. Partially, this is because humic acids are important in coating clay minerals ${ }^{34}$.

Millward and Moore ${ }^{35}$ conducted $\mathrm{pH}$ edge experiments using iron oxyhydroxide as a model solid. The results showed that copper adsorption was salinity independent and adsorption increased rapidly from $\mathrm{pH} 5$ to $\mathrm{pH} 8$. Tien and Huang ${ }^{36}$, and Tijero et al. ${ }^{37}$ studied metal association with wastewater particulates and used Langmuir adsorption isotherms to model the metal behavior by considering effects of surface functional groups. Their results show that adsorption isotherm is linear at small metal loading. McIlroy et al. ${ }^{38}$ studied the adsorption of copper and zinc using river water particles from the Flint River, in Michigan (U.S.A.). The two metals exhibited sharp adsorption edges at $\mathrm{pH}$ values of 4 to 5.5 for $\mathrm{Cu}$ and 6 to 7 for $\mathrm{Zn}$. They also obtained a linear partition behavior for copper up to soluble concentrations of $350 \mu \mathrm{g} \mathrm{L}^{-1}$.

The magnitude of the partition coefficient depends on the characteristics of the adsorption and adsorbing solids. It depends on the $\mathrm{pH}$ of the media, the functional groups on the solid surface and complexation in the solution. Müller and Sigg ${ }^{39}$ studied the partition of zinc and lead in a Swiss river. They determined conditional stability constants and binding capacities. Field measurements and calculated distribution coefficients showed good agreement for both $\mathrm{Zn}$ and $\mathrm{Pb}$. The main components controlling the adsorption to the particles were found to be the organic matter, as well as iron and manganese oxides. 
Grassi et al. ${ }^{13}$ investigated the sorption of copper by natural suspended particles collected from the Delaware River (U.S.A.). The adsorption increased with increasing $\mathrm{pH}$, until $\mathrm{pH}$ 9. An increase of $\mathrm{Cu}$ adsorption proportional to particulate matter concentration was also observed. Similar results were obtained by Shi et al. ${ }^{14}$. These authors used suspended particulate matter collected from three different rivers located in Delaware (U.S.A.). They developed a model, based on copper adsorption onto particles and complexation with dissolved organic matter, to access copper partition coefficients. The model adequately described the system and it was based on easily measurable water quality parameters such as $\mathrm{pH}$, alkalinity, dissolved and particulate organic matter.

Delos et al. ${ }^{40}$ obtained a general equation to predict the partition coefficient in freshwater systems, which shows the dependence of $\mathrm{K}_{\mathrm{d}}$ on the concentration of particles. This dependence has also been reported for marine and estuarine environments ${ }^{41}$. Those simple relationships are thought to be conservative or biased in their estimation ${ }^{42}$. $\mathrm{K}_{\mathrm{d}}$ is, in fact, related to solution composition and sorption characteristics of the particle surface.

The aim of this work was to investigate the adsorption of copper on modified aluminum oxide. This modification was achieved by adsorbing humic acid on the surface of $\mathrm{Al}_{2} \mathrm{O}_{3}$. The modification is important because the organic coating on particles can be manipulated easily. The adsorption was investigated as a function of $\mathrm{pH}$, solids concentration and particulate and dissolved organic matter. Aluminum oxide was used due to its importance as an aquatic sorbent. Moreover, its use overcomes some experimental difficulties associated with experiments using natural suspended particles, which may represent an assemblage of components with different properties, including different surface groups.

Although copper is an essential trace element, it can be toxic to the aquatic biota at moderate levels. The main sources of copper to surface water are the industrial and domestic wastes, mining, and mineral leaching.

\section{Materials and Methods}

\section{Analyses}

A Perkin Elmer 5000 atomic absorption spectrometer coupled with a graphite furnace accessory was used for copper determinations. A hollow-cathode lamp was used, operating at $15 \mathrm{~mA}$ current with an analysis wavelength of $324.8 \mathrm{~nm}$ without background correction. A spectral bandpass of 0.7 $\mathrm{nm}$ was selected. The pyrolysis and atomization temperatures were $1200^{\circ} \mathrm{C}$ and $2300^{\circ} \mathrm{C}$, respectively.
Dissolved organic carbon (DOC) was analyzed using a Beckman 915-B TOC analyzer. The particulate organic carbon was determined using a $\mathrm{CHN}$ analyzer (Europa Scientific).

Analysis of dissolved copper in the solution phase was performed after a syringe filtration through a $0.45 \mu \mathrm{m}$ Nuclepore membrane filter. The amount of adsorbed copper was calculated as the difference between the amount initially added and the remaining in solution after 24 hours of shaking. Shi et al. ${ }^{43}$ conducted metal recovery tests both for dissolved and particulate copper and the results of the mass balance study indicated negligible copper adsorption to the container wall.

\section{Adsorption of Humic Acid on Aluminum Oxide}

A commercial humic acid (sodium salt, Aldrich Chemical) was used to modify the aluminum oxide (Alfa Aesar, gamma, 99.5\%) in order to achieve different levels of particulate organic matter. The adsorption of humic acid (HA) was conducted at $\mathrm{pH}$ 6.0, which was adjusted using $0.1 \mathrm{~mol} \mathrm{~L}^{-1} \mathrm{HNO}_{3}$, with an aluminum oxide concentration of $5.0 \mathrm{~g} \mathrm{~L}^{-1}$. A $2.0 \mathrm{~g} \mathrm{~L}^{-1}$ humic acid stock solution was prepared and used to achieve humic acid concentrations of $400 \mathrm{mg} \mathrm{L}^{-1}$ and $800 \mathrm{mg} \mathrm{L}^{-1}$. The adsorption experiments were performed at room temperature $\left(25 \pm 1{ }^{\circ} \mathrm{C}\right)$, and the bottles were shaken for $24 \mathrm{~h}$ on a Lab-Line Orbit Shaker with a speed of 100 strokes $\mathrm{min}^{-1}$. The percent humic acid adsorbed was calculated by the difference between the initial and the final humic acid concentrations which was based on the dissolved organic carbon (DOC) concentration in each sample. The ratio DOC/HA, determined experimentally, is $30.70 \pm 2.50 \%$, showing a constant behavior during all experiments.

The suspended modified aluminum oxide was air dried inside a laminar flow hood, for $24 \mathrm{~h}$. After that, it was stored at room temperature $\left(25 \pm 1^{\circ} \mathrm{C}\right)$, in the dark, for a period no longer than a week.

\section{Adsorption of Copper on Aluminum Oxide}

Copper adsorption experiments were performed using a batch method. Copper nitrate salt, $\mathrm{Cu}\left(\mathrm{NO}_{3}\right)_{2}$, (Aldrich Chemical) was used to make a standard solution for adsorption and $\mathrm{pH}$ edge experiments. A $100 \mathrm{mg} \mathrm{L}^{-1}$ copper standard solution was prepared for the addition of copper to the suspensions. Since the $\mathrm{pH}$ of the copper solution was between 5.5 and 6.0 , the standard solution was prepared immediately before use to preclude significant metal loss to the container walls. A proper amount of copper was added into $100 \mathrm{~mL}$ bottles containing the suspension and the ionic strength was adjusted to $0.01 \mathrm{~mol} \mathrm{~L}^{-1}$ using $\mathrm{NaNO}_{3}$. For $\mathrm{pH}$ edge experiments, the $\mathrm{pH}$ in each bottle 
was then adjusted in the range of 3.0 and 10.0 using either $0.1 \mathrm{~mol} \mathrm{~L}^{-1} \mathrm{NaOH}$ or $0.1 \mathrm{~mol} \mathrm{~L}^{-1} \mathrm{HNO}_{3}$. After preparation, samples were shaken for 24 hours at $25 \pm 1{ }^{\circ} \mathrm{C}$ with a speed of 100 strokes $\mathrm{min}^{-1}$.

For the experiments of copper adsorption at different initial $\mathrm{Cu}$ (II) concentrations, HA-coated aluminum oxide levels were fixed at $200 \mathrm{mg} \mathrm{L}^{-1}$. The $\mathrm{pH}$ of 6.0 and ionic strength of $0.01 \mathrm{~mol} \mathrm{~L}^{-1} \mathrm{NaNO}_{3}$ were initially adjusted. The range of copper added was from zero to a maximum of $5.0 \mathrm{mg} \mathrm{L}^{-1}$, depending on particulate organic carbon content on $\mathrm{Al}_{2} \mathrm{O}_{3}$

Effect of dissolved organic matter on copper partitioning was performed using $3.54 \% \mathrm{HA}$-coated $\mathrm{Al}_{2} \mathrm{O}_{3}$. The humic acid was added at concentrations of 10,20,40,60,80, and $100 \mathrm{mg} \mathrm{HA} \mathrm{L}^{-1}$. The solids concentration was $200 \mathrm{mg} \mathrm{L}^{-1}$. The $\mathrm{pH}$ was fixed at 6.0 and ionic strength was maintained at $0.01 \mathrm{~mol} \mathrm{~L}^{-1} \mathrm{NaNO}_{3}$.

\section{Results and Discussion}

\section{Adsorption of humic acid onto aluminum oxide}

There are a number of literature reports indicating that natural particles possess organic coatings ${ }^{21,44,45}$. The organic coating will affect metal binding behavior with suspended particles ${ }^{46,47}$.

Figure 1 shows the significant $\mathrm{pH}$ influence on the humic acid adsorption onto aluminum oxide. Accordingly, the humic acid adsorption was preferred at low $\mathrm{pH}$ values. The $\mathrm{pH}_{\mathrm{ZPC}}$ for aluminum oxide is 7.4. Therefore, aluminum oxide surfaces are positively charged at low $\mathrm{pH}(<7.4)$, enhancing the formation of surface complexes with humic acid. The $\mathrm{pH}$ dependent adsorption of humic acid onto $\mathrm{Al}_{2} \mathrm{O}_{3}$ is consistent with an ion exchange mechanism ${ }^{48,49}$.

Figure 2 shows the humic acid adsorption isotherm onto $\mathrm{Al}_{2} \mathrm{O}_{3}$ at $\mathrm{pH} 6.0$ with constant ionic strength of 0.01 mol L-1 $\mathrm{NaNO}_{3}$. The Langmuir equation was used to fit experimental data. The maximum adsorption of humic acid was $6.07 \mathrm{~g}$ per $100 \mathrm{~g}$ of $\mathrm{Al}_{2} \mathrm{O}_{3}$. Previous reports indicated that humic acid adsorption on kaolinite and aluminum oxide occurred on some specific parts of the available surface ${ }^{50,51}$. Therefore, it may be postulated that humic acid molecules occupy either the "surfaces" or the "edges" of the $\mathrm{Al}_{2} \mathrm{O}_{3}$ particles. Under more acidic conditions than pH 6.0, humic acid adsorption on aluminum oxide will increase. Either a large part of the surface is covered or aggregation of molecules may happen ${ }^{52}$. The percent of humic acid, calculated in terms of total humic acid initially present in the solution phase, decreased as the ratio of humic acid to aluminum oxide increased. This indicates that an increase of humic acid concentration in the solution, at a constant $\mathrm{pH}$ of 6.0, will not enhance the degree of HA coating on aluminum oxide particles. When the dissolved organic carbon concentration in the solution phase is higher than $200 \mathrm{mg} \mathrm{L}^{-1}$, the increase in humic acid adsorption on aluminum oxide becomes negligible.

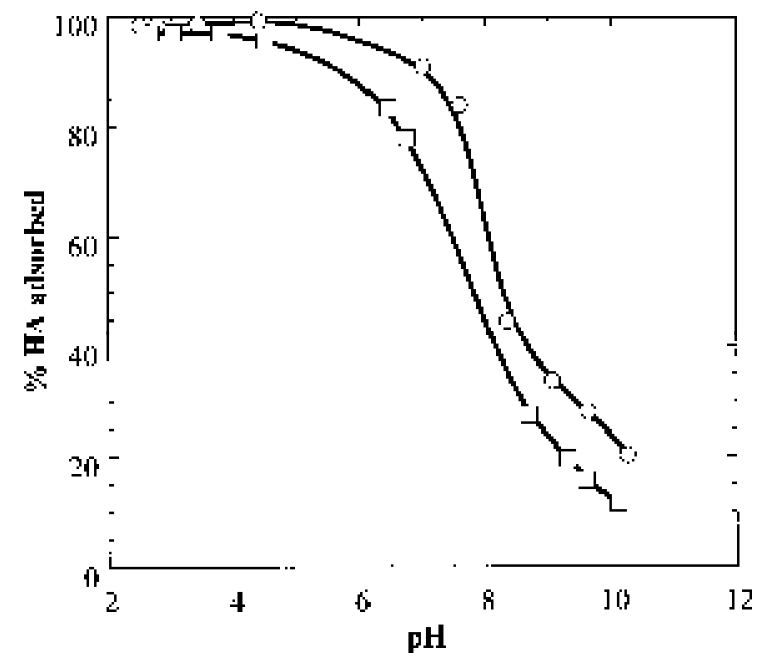

Figure 1. Adsorption of Aldrich humic acid onto aluminum oxide as a function of the $\mathrm{pH}\left(\mathrm{Al}_{2} \mathrm{O}_{3}\right.$ concentration: $5 \mathrm{~g} \mathrm{~L}^{-1}$; humic acid concentrations: $400 \mathrm{mg} \mathrm{L}^{-1}$ (circle) and $800 \mathrm{mg} \mathrm{L}^{-1}$ (square). I = $0.01 \mathrm{~mol} \mathrm{~L}^{-1} \mathrm{NaNO}_{3}$ and $\mathrm{T}=25 \pm 1{ }^{\circ} \mathrm{C}$ ).

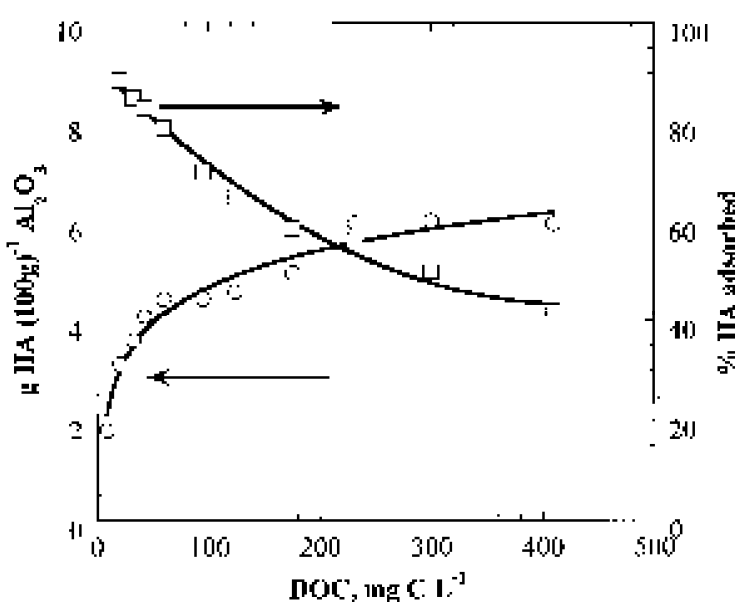

Figure 2. Isotherm for Aldrich humic acid adsorption on aluminum oxide $\left(\mathrm{Al}_{2} \mathrm{O}_{3}\right.$ concentration: $5000 \mathrm{mg} \mathrm{L}^{-1}, \mathrm{pH}=6.0, \mathrm{I}=0.01 \mathrm{~mol} \mathrm{~L}^{-1}$ $\mathrm{NaNO}_{3}$, and $\mathrm{T}=25 \pm 1{ }^{\circ} \mathrm{C}$ ).

\section{Copper adsorption isotherms}

Copper partitioning between dissolved and suspended particulate matter is important because metal distribution in the aquatic environment is related to its effect on fate, bioavailability, and reactivity. Metal interactions between particulates and dissolved components play a very important role in the regulation of dissolved, as well as bioavailable metal concentrations. Adsorption or sorption is the first step 
in the ultimate removal of trace metals from the hydrological cycle with the ultimate sink being the estuary sediments. Changes in environmental parameters such as $\mathrm{pH}$, solids concentration or the discharge of complexing agents affect metal adsorption and desorption processes ${ }^{53}$.

Copper adsorption isotherms for pure and modified aluminum oxide are shown in Figure 3. The lower curve in this figure represents the copper adsorption isotherm for pure aluminum oxide, where no humic acid coating was present. Copper adsorption increased with increasing amounts of the humic acid coating on the aluminum oxide. The maximum adsorption density and conditional adsorption constants can be obtained by non-linear regression using Equation 6.

$\Gamma_{\mathrm{Cu}}=\frac{\Gamma_{\max } \mathrm{K}_{\mathrm{M} / \mathrm{H}}^{\mathrm{s}}\left[\mathrm{Cu}^{2+}\right]}{\left[\mathrm{H}^{+}\right]+\mathrm{K}_{\mathrm{M} / \mathrm{H}}^{\mathrm{s}}\left[\mathrm{Cu}^{2+}\right]}$

where

$\Gamma_{\mathrm{Cu}}$ is the copper adsorption density, $\mu \mathrm{g} \mathrm{mg} \mathrm{m}^{-1}$ of total suspended solids, TSS;

$\Gamma_{\max }$ is the maximum copper adsorption density, $\mu \mathrm{g} \mathrm{mg}^{-1}$; and

$\mathrm{K}^{\mathrm{s}} \mathrm{M} / \mathrm{H}$ is the conditional adsorption constant between copper ion and solids.

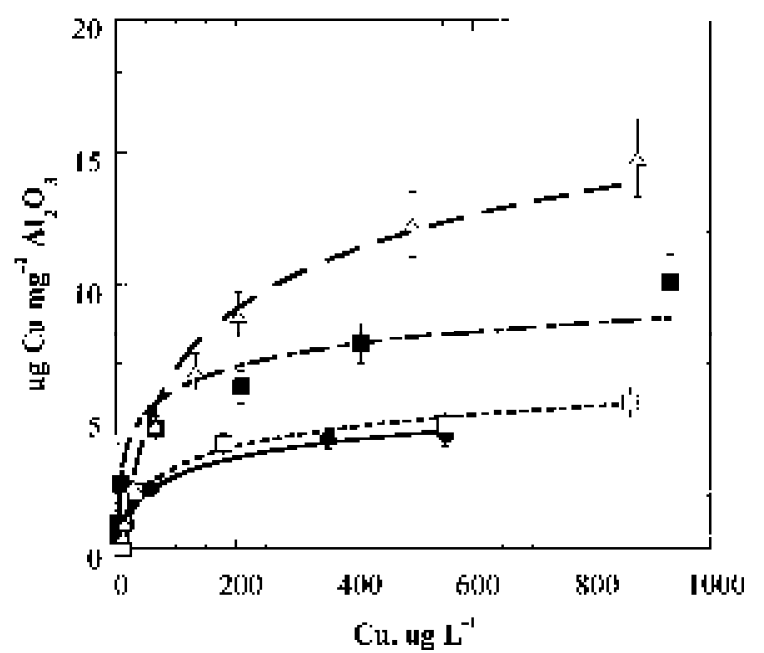

Figure 3. Copper adsorption isotherms for pure aluminum oxide and the humic acid modified aluminum oxide (Humic acid concentrations: $0.0 \%$ (closed circles), $1.4 \%$ (open squares), $3.5 \%$ (closed squares), and $6.0 \%$ (open triangles) TSS $=200 \mathrm{mg} \mathrm{L}^{-1}, \mathrm{pH}$ $6.0, \mathrm{I}=0.01 \mathrm{~mol} \mathrm{~L}^{-1} \mathrm{NaNO}_{3}$, and $\mathrm{T}=25 \pm 1{ }^{\circ} \mathrm{C}$ ).

The adsorption increases with increasing copper concentration and the system tends to reach saturation with additional copper increments. The maximum copper adsorption density for pure aluminum oxide is $4.96 \mu \mathrm{g}$ $\mathrm{mg}^{-1}$ of aluminum oxide and that for the $6 \% \mathrm{HA}$-coated aluminum oxide is $18.2 \mu \mathrm{g} \mathrm{mg}^{-1}$ of $\mathrm{Al}_{2} \mathrm{O}_{3}$. Clearly, it shows that copper adsorption increases with an increase of humic acid coating onto aluminum oxide.

\section{pH edge experiments for copper adsorption}

The influence of the $\mathrm{pH}$ on the adsorption of copper onto $\mathrm{Al}_{2} \mathrm{O}_{3}$ is presented in Figure 4. Aluminum oxide with $3.54 \%$ humic acid coating was used to perform $\mathrm{pH}$ edge experiments. The solids concentration was $200 \mathrm{mg} \mathrm{L}^{-1}$ and the $\mathrm{pH}$ covered the range from 3 to 10 . This figure shows a pH edge plot including modified $\mathrm{Al}_{2} \mathrm{O}_{3}$ suspended in ultrapure water and $\mathrm{Al}_{2} \mathrm{O}_{3}$ suspended in a $20 \mathrm{mg} \mathrm{HA} \mathrm{L}^{-1}$ solution. For both cases, at low $\mathrm{pH}$, almost all the copper remains in solution. For the $\mathrm{pH}$ edge conducted using the ultra-pure water, the percent of copper adsorption increased as $\mathrm{pH}$ changed from low to high values until $\mathrm{pH} 9$. The percent of copper adsorption exhibits a slight decrease when $\mathrm{pH}$ was further increased.

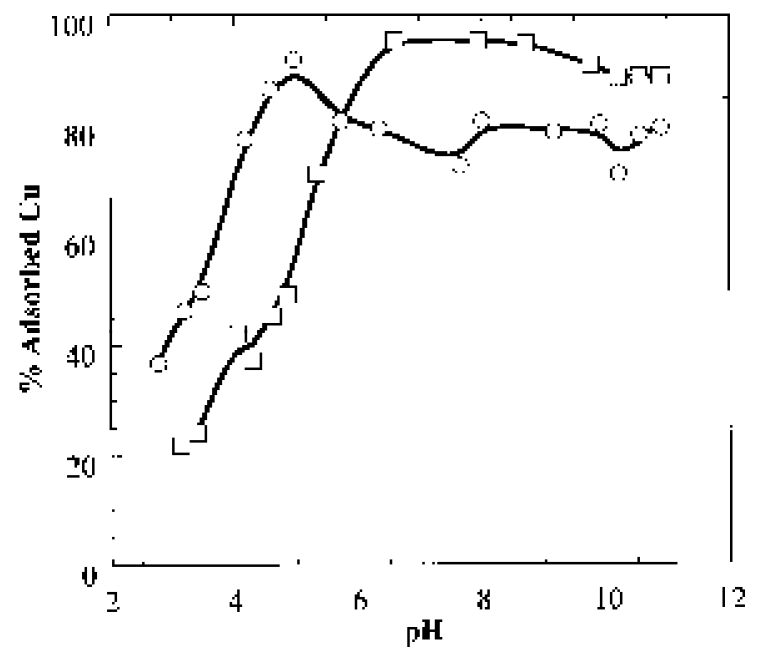

Figure 4. Adsorption of copper on $3.54 \%$ humic acid-coated aluminum oxide (performed in ultra-pure water (squares) and in ultra-pure water with addition of $20 \mathrm{mg} \mathrm{HA} \mathrm{L}^{-1}$ (circles). TSS $=200$ $\mathrm{mg} \mathrm{L}-1, \mathrm{I}=0.01 \mathrm{~mol} \mathrm{~L}^{-1} \mathrm{NaNO}_{3}$, and $\mathrm{T}=25 \pm 1{ }^{\circ} \mathrm{C}$ ).

The $\mathrm{pH}$ is one of the most important factors controlling the adsorption of a metal onto suspended particles. As the $\mathrm{pH}$ increases, it is usually expected that the adsorption also increases. When the $\mathrm{pH}$ is reduced, surface charge of the particles becomes increasingly positive ${ }^{54}$ and because of the competition of the hydrogen ions for the binding sites, metals tend to desorb at low $\mathrm{pH}$ values. Consequently, the metal adsorption is unfavorable at this $\mathrm{pH}$ region.

A small decrease in copper adsorption was observed in this study at $\mathrm{pH}$ higher than 9 . This behavior may be due to the formation of soluble copper-carbonate and copperhydroxide complexes ${ }^{55}$, and the dissolution of organic 
matter from the suspended particles resulting in an increase in metal complexation. Instead of copper attachment to particle surface, it is also possible to form small precipitates with sizes less than $0.45 \mathrm{~mm}$. Those colloidal materials may remain in solution, and are included as part of the dissolved component. Elliot and Huang ${ }^{54}$ showed similar dips for copper adsorption onto aluminum oxide when amino acids were present. Grassi et al. ${ }^{13}$ and Shi et al. ${ }^{14}$ also describe the same type of behavior for copper adsorption in experiments using natural riverine suspended particles.

For the $\mathrm{pH}$ edge experiments conducted using the 20 mg HA L ${ }^{-1}$ solution, the copper adsorption increased in the low $\mathrm{pH}$ region, reaching a maximum at $\mathrm{pH}$ of 5 , and decreased as the $\mathrm{pH}$ was further increased. Davies ${ }^{45}$ reported an increase of DOC adsorption onto an oxide surface at low $\mathrm{pH}$. Thus, it is postulated that part of the added humic acid may be adsorbed onto aluminum oxide at low $\mathrm{pH}$, resulting in an increased copper partitioning. The adsorption of the humic acid is unlikely to occur at high $\mathrm{pH}$ values. Therefore, additional humic acid, as opposed to the previous case, will enhance copper complexation in the dissolved phase. As a result, the degree of copper adsorption on modified aluminum oxide will be low. This demonstrates that partitioning of copper onto solids was unfavorable when humic acid in the solution phase was increased.

A series of batch experiments were conducted, and the dissolved organic carbon was determined, using the same conditions as those for the experiments shown in Figure 4. The DOC values as a function of the $\mathrm{pH}$ are shown in Figure 5. DOC increases with increased $\mathrm{pH}$. The amount of DOC desorbed, in the case of $\mathrm{Al}_{2} \mathrm{O}_{3}$ suspended in the ultra-pure water, is solely from HAcoated $\mathrm{Al}_{2} \mathrm{O}_{3}$ particles. As the DOC increases, there must be an equivalent decrease of particulate organic carbon on $\mathrm{Al}_{2} \mathrm{O}_{3}$ particles to maintain a mass balance for humic acid. The DOC desorbed from $\mathrm{Al}_{2} \mathrm{O}_{3}$ particles in ultrapure water is less than about $1.2 \mathrm{mg} \mathrm{L}^{-1}$ when the $\mathrm{pH}$ is below 7. In the other case, i.e., $\mathrm{Al}_{2} \mathrm{O}_{3}$ suspended in 20 mg HA L ${ }^{-1}$ solution, the final DOC concentration will be the result of the initial DOC concentration plus the amount of carbon desorbed from $\mathrm{Al}_{2} \mathrm{O}_{3}$ particles, which occurs when the solution $\mathrm{pH}$ is high. However, additional dissolved organic matter adsorbs onto $\mathrm{Al}_{2} \mathrm{O}_{3}$ particles when the solution $\mathrm{pH}$ is low. In this case, the DOC concentration will be the result of initial DOC concentration minus the amount of carbon adsorbed onto aluminum oxide particles. Consequently, copper adsorption in the low $\mathrm{pH}$ region will be higher as shown in Figure 4. The degree of copper adsorption is higher for the addition of $20 \mathrm{mg} \mathrm{HA} \mathrm{L}^{-1}$, and lower for the ultrapure water.

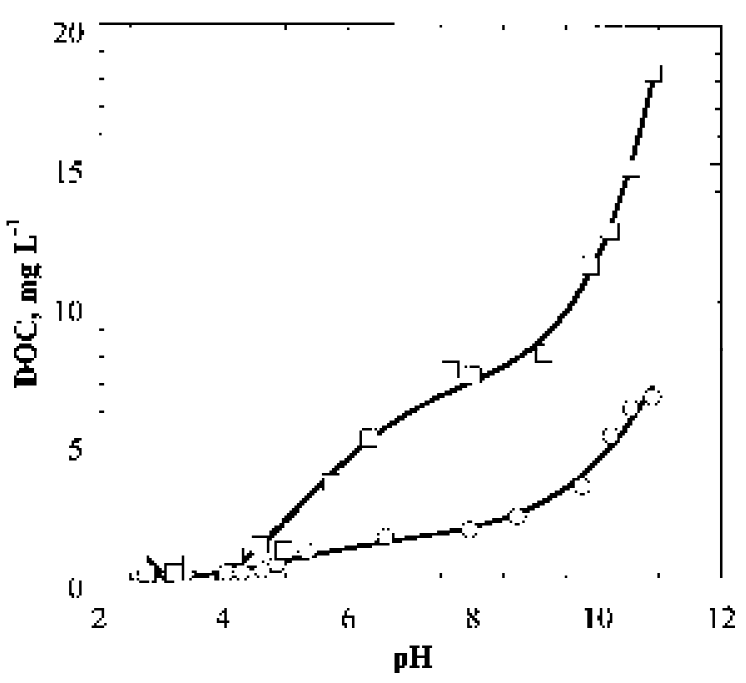

Figure 5. Dissolved organic carbon (DOC) from 3.54\% HA-coated aluminum oxide as a function of the $\mathrm{pH}$ (Conditions are those shown in Fig. 4).

Influence of solids concentration on copper adsorption

Aluminum oxide with humic acid coating of $3.54 \%$ and $0.263 \%$ was used to study the effect of solids on copper partitioning. Figures 6(a) and 6(b) show these results. The general pattern for these results is that the partition coefficient decreased as the solids in the systems increased. This functional relationship of the partition coefficient with total solids concentration has been discussed by many investigators ${ }^{12-14,56}$. This may be explained by changing in adsorption surface area on particles per mass of suspended solids. The pH effect in Figure 6(a) is consistent with the observations from $\mathrm{pH}$ edge experiments. Copper partitioning will be the highest at neutral $\mathrm{pH}$ and it decreases at $\mathrm{pH} 6.0$ or $\mathrm{pH}$ 8.0. However, the results in Figure 6(b) show that the partition coefficient increased as $\mathrm{pH}$ increased. For this low humic acid coating, most of the particles will exhibit metal oxide properties. Dzomback and Morel $^{32}$ concluded that adsorption of metals increased from low to $100 \%$ within a very narrow $\mathrm{pH}$ range, usually 1 to $2 \mathrm{pH}$ units. In the simple oxide/water system, where organic matter is absent, metal adsorption always increases as $\mathrm{pH}$ increases.

\section{Influence of dissolved organic carbon on copper adsorption}

The effect of dissolved organic matter on copper partitioning was performed using 3.54\% $\mathrm{HA}$-coated $\mathrm{Al}_{2} \mathrm{O}_{3}$. The copper partition coefficient is shown in Figure 7. As dissolved organic carbon concentration increases, a large portion of metal was complexed with DOC, resulting in a decrease in the amount of particulate copper. However, a portion of added humic acid may be attached onto aluminum oxide surface at the experimental $\mathrm{pH}$ of 6.5. This will reduce 

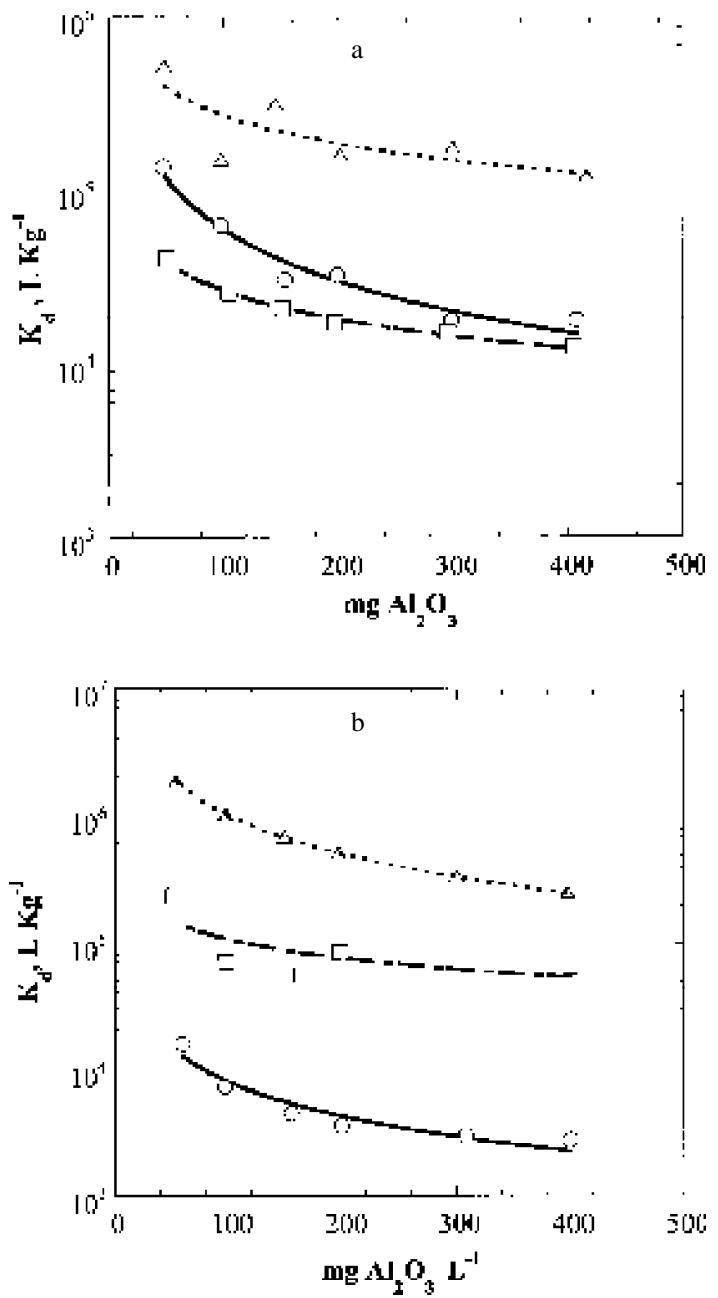

Figure 6. Copper partition coefficient $\left(\mathrm{K}_{\mathrm{d}}\right)$ for modified aluminum oxide concentration from 50 to $450 \mathrm{mg} \mathrm{L}^{-1}$. (a) Humic acid coating: $3.54 \%$. pH values: 5 (squares), 7 (triangles) and 8 (circles); (b) Humic acid coating: $0.236 \%$. pH values: 6 (circles), 7 (squares), and 8 (triangles). $\mathrm{I}=0.01 \mathrm{~mol} \mathrm{~L}^{-1} \mathrm{NaNO}_{3}, \mathrm{~T}=25 \pm 1{ }^{\circ} \mathrm{C}$.

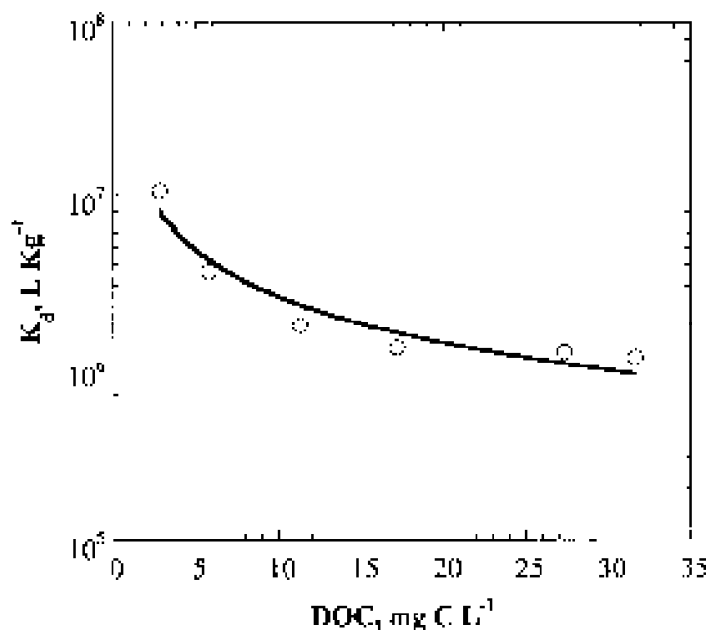

Figure 7. Copper partition coefficient $\left(\mathrm{K}_{\mathrm{d}}\right)$ for $3.54 \%$ HA-coated aluminum oxide determined at different DOC concentrations (TSS $=$ $200 \mathrm{mg} \mathrm{L}^{-1} \cdot \mathrm{pH}=6.0 . \mathrm{I}=0.01 \mathrm{~mol} \mathrm{~L}^{-1} \mathrm{NaNO}_{3}$, and $\left.\mathrm{T}=25 \pm 1{ }^{\circ} \mathrm{C}\right)$. the degree of solution metal complexation. The difference between the added humic acid and that remaining in solution after equilibrium is $5 \mathrm{mg} \mathrm{C} \mathrm{L}^{-1}$ at the highest dose of $100 \mathrm{mg}$ $\mathrm{L}^{-1}$. Therefore, an increase in particulate organic carbon due to addition of humic acid is small. The metal complexation in the solution phase is predominant ${ }^{57}$.

\section{Conclusions}

Copper adsorption onto HA-coated aluminum oxide, used as an aquatic model phase, is strongly influenced by $\mathrm{pH}$, solids concentration, and organic matter content. When $\mathrm{pH}$ is low, copper adsorption is insignificant due to hydrogen ion competition for adsorption sites. In the case of high $\mathrm{pH}$ values (above 9), copper adsorption decreases because of the formation of soluble metal carbonate and hydroxides or metal organic complexes. The copper adsorption can strongly be correlated to the content of adsorbed organic carbon. An increase of adsorbed organic carbon enhances the copper uptake and vice-versa. Copper partitioning is maximal at the neutral $\mathrm{pH}$ region and decreases at both low and high $\mathrm{pH}$ values. The fate of copper in natural waters depends on such partitioning characteristics in the solid-solution system. A high degree of metal adsorption occurs when the $\mathrm{pH}$ is nearly neutral, the particulate organic matter is high, and the concentration of solids is elevated. Under these conditions minor fractions of metals will be available to aquatic biota.

Understanding of copper binding forms in the water environment is crucial to the quality and management of water and wastewater, especially for the re-evaluation of Water Quality Criteria for the metals in natural water so that they are neither over nor under protective for aquatic organisms.

\section{Acknowledgments}

The authors wish to thank Delaware River Basin Commission, U.S. Environmental Protection Agency, and Delaware Water Resources Center, for financial support. They also gratefully acknowledge Mr. Huizhong Ma for the help with solids modification. MT Grassi was funded by CNPq, Brazil. Helpful discussion with Drs. MM Kondo and LR Takiyama are also acknowledged.

\section{References}

1. Hart, B. Hydrobiol. 1882, 91, 299.

2. Davis, J. A.; Leckie, J. O. Environ. Sci. Technol. 1978, 12, 1309.

3. Stiff, M. J. Water Res. 1971, 5, 585. 
4. Windom, H. L.; Byrd, J. T.; Smith Jr., R. G.; Huan, F. Environ. Sci. Technol. 1991, 25, 1137.

5. McBride, M. B. Adv. Soil Sci. 1989, 10, 1.

6. Evans, L. J. Environ. Sci. Technol. 1989, 23, 1046.

7. Christensen, T. H. Water, Air, Soil Pollut. 1989, 44, 71.

8. Lee, S. Z.; Allen, H. E.; Sparks, D. L.; Sanders, P. F.; Peijnenburg, W. J. G. M. Environ. Sci. Technol. 1996, 30, 3418.

9. Yin, Y.; Allen, H. E.; Huang, C. P.; Li, Y.; Sanders, P. F. J. Environ. Qual. 1996, 25, 837.

10. Huang, C. P.; Stumm, W. J. Colloid Interface Sci. 1973, 43, 409.

11. Huang, C. P.; Rhoads, E. A.; Hao, O. J. Water Res. 1988, 22, 1001.

12. Benoit, G.; Oktay-Marshall, S. D.; Cantu, A.; Hood II, E. M.; Coleman, C. M.; Carapcioglu, M. O.; Santschi, P. H. J. Mar. Chem. 1994, 45, 307.

13. Grassi, M. T.; Shi, B.; Allen, H. E. Int. J. Colloids Surf., A 1997, 120, 199.

14. Shi, B.; Allen, H. E.; Grassi, M. T.; Ma, H. Water Res. 1998, 32, 3756.

15. Huang, C.; Huang, C. P.; Morehart, A. L. Water Res. 1991, 25, 1365.

16. Shi, B.; Sengupta, A. K. In Water Research for the New Decade, 1991 Annual Conference Proceedings, American Water Works Association, Philadelphia, 1991, p 875.

17. Fu, G.; Allen, H. E.; Cao, Y. Environ. Toxicol. Chem. 1992, 11, 1363.

18. Whitehouse, B. G.; Yeats, P. A.; Strain, P. M. Limnol. Oceanogr. 1990, 35, 1368.

19. Douglas, G. B.; Beckett, R.; Hart, B. T. Hydrol. Proc. 1993, 7, 177.

20. Horowitz, A. J.; Elrick, K. A.; Hooper, R. C. Hydrol. Proc. 1989, 2, 163.

21. Tipping, E. Geochim. Cosmochim. Acta 1981, 45, 191.

22. Luther III, G.; Wilk, Z.; Ryans, R. A.; Meyerson, A. L. Mar. Pollut. Bull. 1986, 17, 535.

23. Raspor, B.; Valenta, P. J. Mar. Chem. 1988, 25, 211.

24. Lion, L. W.; Altmann, R. S.; Leckie, J. O. Environ. Sci. Technol. 1982, 16, 660.

25. Huang, C.; Yang, Y. L. Water Res. 1995, 29, 2455.

26. Thurman, E. M. Organic Geochemistry of Natural Waters; Kluwer Academic; Boston, 1985.

27. Sposito, G. The Surface Chemistry of Soils; Oxford University Press; New York, 1984.

28. Hohl, H.; Stumm, W. J. Colloid. Interface Sci. 1976, 55, 281.

29. Schindler, P. W. In Adsorption of Inorganics at Solid-Liquid Interfaces, Anderson, M.A.; Rubin, A.J., Eds., Ann Arbor Science Publishers; Ann Arbor, 1981, p 1.
30. Singh, U.; Uehara, G. In Soil Physical Chemistry, Sparks, D. L., Ed.; CRC Press; Boca Raton, 1986, p 56.

31. Buffle, J. In Metal Ions in Biological Systems, Sigel, H., Ed.; Marcel Dekker; New York, 1984, p 165.

32. Dzomback, D. A.; Morel, F. M. M. J. Hydraul. Eng. 1987, 113, 430.

33. Kinniburgh, D. G. J. Soil Sci. 1983, 34, 759.

34. Davis, J. A. Geochim. Cosmochim. Acta 1984, 48, 679.

35. Millward, G. E.; Moore, R. M. WaterRes. 1982, 16, 981.

36. Tien, C. T.; Huang, C. P. J. Environ. Engrg. 1987, 113, 285.

37. Tijero, J.; Martin, M. J.; Mirada, F. J. Separation Sci. Technol. 1986, 23, 273.

38. McIlroy, L. M.; DePinto, J. V.; Young, T. C.; Martin, S. C. Environ. Toxicol. Chem. 1986, 5, 609.

39. Müller, B.; Sigg, L. Aquatic Sci. 1990, 52, 75.

40. Delos, C. G.; Richardson, W. L.; DePinto, J. V.; Ambrose, R. B.; Rogers, P. W.; Rygwelski, K.; St. John, J. P.; Shaughnessy, W. J.; Faha, T. A.; Christie, W.N. In Streams and Rivers; U. S. Environmental Protection Agency; Washington, 1984.

41. Honeyman, B. D.; Santschi, P. H. Environ. Sci. Technol. 1988, 22, 862.

42. Sung, W. In Surface Water Quality and Ecology; WEFTEC'94 Conference and Exposition, Vol. 4; Water Environment Federation; Chicago, 1994, p 549.

43. Shi, B.; Grassi, M.T.; Allen, H.E.; Fikslin, T.J.; Kinerson, R.S. In Surface and Water Quality and Ecology WEFTEC'96 Conference and Exposition, Vol. 4; Water Environment Federation; Dallas, 1996, p 511.

44. Neihof, R. A.; Loeb, G. J. Limnol. Oceanogr. 1972, $17,7$.

45. Davis, J. A. Geochim. Cosmochim. Acta 1982, 46, 2381.

46. Oakley, S. M.; Nelson, P. O.; Williamson, K. J. Environ. Sci. Technol. 1981, 15, 474.

47. Spitzy, A.; Lttekkot, V. Ocean Margin Processes in Global Change; John Wiley; New York, 1991.

48. Tipping, E.; Cooke, D. Geochim. Cosmochim. Acta 1982, 46, 75.

49. Stumm, W. Chemistry of the Solid-Water Interface: Processes at the Mineral-Water and Particle-Water Interface in Natural Systems; John Wiley: New York, 1992.

50. Dalang, F.; Buffle, J.; Haerdi, W. Environ. Sci. Technol. 1984, 18, 135.

51. Schlautman, M. A.; Morgan, J. J. Environ. Sci. Technol. 1993, 27, 2523.

52. Park, J. W.; Jaffe, P. R. Environ. Sci. Technol., 1993, 27, 1306.

53. Solomons, W.; Förstner, U. Metals in the Hydrocycle; Springer-Verlag; Berlin, 1984. 
54. Elliott, H. A.; Huang, C. P. Environ. Sci. Technol. 1980, $14,87$.

55. Stumm, W.; Morgan, J. J. Aquatic Chemistry: An Introduction Emphasizing Chemical Equilibria in
Natural Waters; 3rd Edition; John Wiley; New York, 1981. 56. O'Conner, D. J.; Connolly, J.P. Water Res. 1980, 14, 1517. 57. Kerndorff, H.; Schnitzer, M. Geochim. Comochim. Acta 1980, 44, 1701.

Received: April 16, 1999

Published on the web: September 15, 2000 